\title{
地中熱利用における課題と地下水学からのアプローチ
}

\author{
阪田義隆* ·長野克則*

\section{Current Problems for Shallow Geothermal Utilization and Approaches to Solve in Groundwater Researches}

\author{
Yoshitaka SAKATA* and Katsunori NAGANO*
}

\begin{abstract}
要旨
地中熱利用への関心の高まりに対し, 設備導入件数が伸び悩む現状の課題に依然コスト削減があ るとし, 近年の研究動向を踏まえた地下水学からの解決アプローチを論じた。クローズドループシス テムでは熱移流を考慮した地中熱交換器規模の削減を挙げ,このための設計性能予測ツール, 設計に 必要な地下水流速のデータベースや原位置試験法を紹介した。オープンループシステムは, 带水層蓄 熱に対する規制緩和の動きから今後導入拡大が期待される中, 井戸の目詰まりリスク等の導入指標 とその評価法の確立, 設計に用いる帯水層データベース構築を課題とした。最後に海外先進事例を紹 介し, わが国の地下水資源を活かす積極的な地中熱利用への期待を述べた。
\end{abstract}

キーワード : 地中熱, ヒートポンプシステム, 移流効果, 帯水層蓄熱

\section{1.はじめに}

日本地下水学会が60周年を迎えるのに際し，地 中熱利用の一層の普及に向けた現状の課題に対 し, 地下水学的視点に基づく解決へのアプローチ を近年の国内外の研究成果を踏まえながら考察 した。わが国の地中熱研究の動向は, 既に落藤 (2002) や長野 (2007a, b), Nagano (2015) がと りまとめている。本誌でも, 藤縄 (2011) ほかに よる誌面講座「地下熱利用技術」において理論か ら設計に至る各分野の詳細な解説がなされた。ま た井岡ほか（2018）により特集「地下水と地熱・ 地中熱エネルギーの利用」では近年の地中熱研究 の成果が報告された。本稿では，これらに対し屋 上屋を重ねることをできるだけ避け，近年とくに 2010年以降の地中熱研究の動向に注目しながら考
察を行った。

\section{2. 地中熱利用の関心の高まりと導入実態}

わが国の社会システムを大きく変える契機と なった一つに2011年 3 月11日の東日本大震災が挙 げられる。とりわけエネルギー分野では，その二 次災害としての福島第一原発事故を機にエネル ギー需給構造の抜本的見直しと全部門に渡るエネ ルギー消費量の削減が急務となった。また大震災 以降, 発電への化石燃料の依存度が高くなったこ とから, 温室効果ガス排出量削減に向けた国際公 約達成の上でもエネルギー消費量削減の徹底が求 められている。実際，わが国のエネルギー消費量 は大震災以降，減少傾向にあり，2016年時点1.3 $\times 10^{4} \mathrm{PJ} / \mathrm{y}, \quad \mathrm{CO}_{2}$ 排出量 $1.2 \times 10^{9} \mathrm{t} / \mathrm{y}$ に相当してい

* 北海道大学大学院工学研究院 ( $\overline{\mathrm{T}} 060-8628$ 北海道札幌市北区北13条西 8 丁目) 
る（経済産業省，2017）。しかしながら部門別で 見る場合, 全消費量の約 3 割を占める業務・家庭 部門では減少ペースが鈍く, 1990年比で未だ約 20\%も多い状態が続いており，その削減が課題と なっている（国土交通省，2019）。こうした背景 において，「エネルギー基本計画」(2014 年 4 月 11日閣議決定）では同部門に対する対策方針とし て，2030年までに新築建物の平均で, 快適な室内 環境を前提に消費エネルギーゼロを目指すZero Energy Building (ZEB) /Zero Energy House (ZEH) の実現が明記された。また「建築物のエネルギー 消費性能の向上に関する法律」が2019年11月16 日から施行され，一定規模 (現行, 延床面積 $2000 \mathrm{~m}^{2}$, 将来想定, 同 $300 \mathrm{~m}^{2}$ ) 以上の非住宅建 築物は新築時にエネルギー消費量を計算し，基準 に適合することが義務化された。また住宅に対し てもトップランナー基準が設けられ，特定建設工 事業者へ必要に応じて省エネ性能向上に向けた勧 告や命令ができるようになった。

地中熱は, 再生可能エネルギーの内, どこでも いつでも使うことができ, 熱源として安定する利 点を有する。わが国では古くから入浴（温泉）や 融雪に地下水を汲み上げ熱源に利用してきたが, 近年はヒートポンプと組み合わせて利用する，い わゆる地中熱ヒートポンプ (Ground Source Heat Pump: GSHP) システムが, 省エネ基準適合や ZEB/ZEH を実現するための高効率設備として関 心が高まっている。こうした関心に応える国の動 きとして, 環境省は「地中熱利用にあたってのガ イドライン」(2015年改訂, 2018年増補) を作成 したほか，2013年には国交省が「公共建築工標準 仕様書（機械設備工事編）」として設計・施工法 を標準化した。また省エネ基準適合計算プログラ ムでもGSHPシステムを選択し, 省エネ適合判 定時にその性能を見積もることができる（建築研 究所, 2017)。各地方自治体では地域の導入ポテ ンシャルを評価しマップとして公開する動きがあ るほか（例えば東京都，2014など），民間でも特 定非営利活動法人地中熱利用促進協会が施工マ ニュアルの作成, 講習会・講演会の開催などを通 じ啓蒙に努めているほか, 各地域にも地中熱の研 究会が組織され，それぞれ普及活動を行ってい る。本学会でも, 前述のとおり地中熱関連の論文
や特集が2010年以降相次ぎ学会誌に発表されてお り, 春季・秋季講演会でも「地中熱」セッション が定着し, 学会員の関心の高いトピックとなって いる。

こうした地中熱利用への関心や普及に向けた動 きの一方，わが国の GSHP システムの年間導入 数は，2013年の約350件をピークに減少傾向に転 じ，2017年には200件以下まで落ち込んでいる(環 境省，2018）。諸外国が再生可能エネルギーへの 関心から地中熱利用を着実に進めている（Lund and Boyd, 2016）のと対照的に，わが国では導入 件数が伸び悩んでいるのが現状である。また環境 省（2018）によれば, 導入したGSHP システム の 9 割がクローズドループシステムとなってい る。わが国には豊富な地下水資源があり, 各地で 地下水を積極的に汲み上げ生活や産業に使用して いるにも関わらず，汲み上げた地下水からヒート ポンプを通して熱利用するオープンループシステ ムの導入は現状，限られている。

\section{3. 地中熱利用の普及に向けた課題とアプロー 于}

\section{1 地中熱利用における課題}

北海道大学では GSHP システム導入の課題を 分析すべく, 2017年に人口 5 万人以上の全国409 自治体を対象にアンケート調査を実施した（阪田 ほか, 2020)。その結果によれば, GSHP システ ムを「知っている」とした回答は 9 割に達し, 認 知が進んでいる一方, 実際に公共施設へ導入した 回答は63件 $(15 \%)$ に留まり, 実際の導入が進ん でいない現状が明らかになった。また導入時の課 題に対する回答としては,「導入コストの低減」 $(33 \%)$,「運用によるコスト回収試算法の確立」 $(15 \%)$ ，「国などからの補助金増額」（8％）が挙 げられ，コストを導入の課題とする回答が半数以 上を占めた。本調査は自治体を対象にしたが，個 人や企業の場合は, 自治体に比ベコスト意識が更 に高くなると予想されることから，地中熱利用の 普及の鍵は依然コスト削減にあると言える。

GSHP システムでは, 地中熱交換器の設置分の コストが上乗せされるため，コスト削減には，ま ず地中熱交換器の規模（鉛直型地中熱交換器の場 
合, 総延長 $=$ 長さ $\times$ 本数）をできるだけ削減する ことが求められる。しかしながら, わが国では, 地中熱利用の需要のある都市の大半が堆積平野 . 盆地に立地し, 未固結な第四紀層が厚く堆積す る。こうした地盤では, 欧米のような岩盤主体の 地盤に比べ, 有効熱伝導率が相対的に低く, 同一 の熱負荷に対しょり大きな規模の地中熱交換器が 必要になる。加えて, 未固結地盤では孔壁保護の ケーシング挿入や泥水処理などに手間がかかるほ か, 建物密集地での運搬や騒音対策などが掘削コ ストを押し上げる。新エネルギー・産業技術総合 開発機構 NEDO（2017）によれば，戸建住宅向 けGSHP システムの初期コストは米国に比べ約 1.5 倍, 特に地中熱交換器工事が約 2 倍との試算 が示された。こうした背景から, 同機構は GSHP システムのコスト削減を目的に2013〜2018年度に かけて「自然再生可能エネルギー利用熱技術開発」 を実施した。この NEDO 事業では, 著者らも含 む15事業者により掘削機や地中熱交換器などの一 次側からヒートポンプや制御システムなどの二次 側, 地中熱利用ポテンシャル評価まで網羅する研 究開発が行われ，これら成果の実用化を通じて目 標とする $20 \%$ のスト削減の見込みが示された (新エネルギー・産業技術総合開発機構, 2017)。

未固結地盤における地中熱利用は, 熱伝導の 点では必ずしも有利ではないが, 带水層中を地 下水が流れる場合には移流効果が加わることに よって, 地盤からの採熱量の増大と地中熱交換 器の削減効果が期待できる。これまでの地中熱 交換器の設計では地下水流れの有無によらず深 度当たり 40～60 W/m の採熱量として延長を決定 している。しかし地下水流れがある場合，80 $100 \mathrm{~W} / \mathrm{m}$ の採熱量が見込める可能性があり (VDI, 2001), その場合には地中熱交換器の延長を大幅 に削減，場合によっては半減できることになる。

また，これまでクローズドループシステムが導 入の大半を占めていたが, コスト削減の観点から は, オープンループシステムも今後, 有望とな る。クローズドループシステムでは熱負荷の増大 に対し比例的に地中熱交換器を埋設する必要があ るが, オープンループシステムの場合, 一本の井 戸で揚水量を増やせば採熱量も増やすことができ るため, 熱負荷が大きい大規模施設になるほどコ
スト的に有利となる。特に欧米では季節間蓄熱 が可能な帯水層蓄熱システム (Aquifer Thermal Energy Storage System: ATES) の導入が進んで いる。

本説では, 今後, わが国の地中熱利用の普及に 向けた課題として依然コスト削減があるとし, そ の解決に向けた地下水学からのアプローチとし て, 移流を考慮した地中熱交換器規模の削減と オープンループシステム, 特に ATES の導入拡大 を挙げ, 最近の研究成果を紹介しながら, その有 効性や今後の課題について述べる。

\section{2 地下水流れの移流効果}

地下水流れがある場合, 地盤中の熱移動には伝 導だけでなく移流も加わることで, 採放熱時の地 中温度変化が抑えられ，ヒートポンプヘ入る熱媒 体温度が安定し, 低い消費電力とシステム性能の 向上が期待できる。特にわが国では, 地形が起伏 に富むことから，動水勾配が大きく，地下水流れ が速い地域が多いと考えられる。既往研究でも GSHP システムの移流効果を考慮した地中熱利用 ポテンシャルとして各地域で, その効果が示され てきた（Fujii et al., 2007; 内田ほか, 2010 ; シュ レスタほか, 2015など)。

地中熱交換器の採熱性能に移流効果が現れる目 安は, ダルシー流速にして $\left.10^{-8} \mathrm{~m} / \mathrm{s} （ \fallingdotseq 0.3 \mathrm{~m} / \mathrm{y}\right)$ 以上とされ (Ferguson, 2015), この程度の流速 条件は多くの地盤で遭遇しうる。ただ，実質的 な効果は地下水流速だけでなく, 熱負荷や熱伝導 との相対関係で決まる。例えば, 熱負荷が小さい 場合, 伝導だけでも地中温度があまり変化しなけ れば移流効果は無視される。同様に有効熱伝導率 が充分大きい地盤であれば, 地中温度はやはり安 定し移流効果は無視される。また地下水流速が速 ければ比例的に効果が得られるわけでなく, 地中 温度が安定する流速でその効果は収束する。阪田 ほか（2018a）は，戸建住宅への10 kW 級 GSHP システムにおいて 20 年ライフサイクルコストを最 小とする地中熱交換器長さを有効熱伝導率, ダル シー流速の異なる組み合わせで計算した。その結 果, 地中熱交換器長さの削減効果は, ダルシー 流速が $20 \mathrm{~m} / \mathrm{y}$ 以上で現れ, 削減量はダルシー流 速の対数に比例しながら, $200 \mathrm{~m} / \mathrm{y}$ を境に収束す 
る。地盤の有効熱伝導率によっても削減効果は異 なり，有効熱伝導率が低い $(1 \mathrm{~W} /(\mathrm{m} \cdot \mathrm{K}))$ 場 合は最終的に約 4 割の削減が見込めるが，高い $(2$ $\mathrm{W} /(\mathrm{m} \cdot \mathrm{K})$ ) 場合, 約 1 割の削減に留まる(図 1 )。

こうした移流効果を考慮した地中熱交換器規模 の設計には，地下水流速だけでなく有効熱伝導 率，熱負荷を考慮した地中温度，ヒートポンプ性 能を計算するシミュレーションツールが必要とな

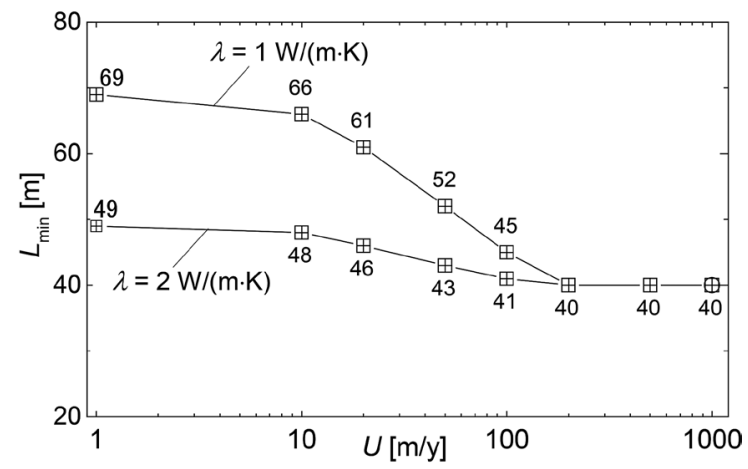

図 1 戸建住宅向け冷暖房 GSHP システムにおけるダル シー流速 Uと 20 年ライフサイクルコスト最小とな る地中熱交換器長さ $L_{\min }$ の異なる有効熱伝導率 $\lambda$ に 対する関係 (阪田ほか, 2018a より再作図)

Fig. 1 Relationships of borehole heat exchanger lengths for minimum 20y-LCC with Darcy velocities in two different cases of effective thermal conductivity.
る。北海道大学が開発した設計性能予測ツール Ground Club は現在，有効熱伝導率の全国データ ベース（Sakata et al., 2020）と組み合わせ，地下 水流れを有する複層地盤条件にも対応した計算 が可能であり（葛ほか, 2015），先述の NEDO 事 業においてクラウド技術を活用した Ground Club Cloud として開発された。

移流効果を考慮した地中熱交換器設計をするに は地下水流速を推定する必要がある。なお地盤中 の熱輸送では，伝導対流の支配方程式中の流速と して，ダルシー流速が分かればよい。予備設計段 階では, 地下水流動シミュレーションによる推定 值を用いるのが現実的である。著者らは全国62流 域における地下水賦存量調査（産業技術総合研 究所，2008）のシミュレーションモデルをベー スに，地形高解像度化による境界水位，阪田ほ か (2018b) による透水係数分布を再入力して計 算を行い, $500 \mathrm{~m}$ グリッドでの地下水流速デー夕 ベースを整備した（Sakata et al., 2019，図 2)。

一方, 実施設計段階では原位置試験, 特に熱応答 試験データから，より精度の高いダルシー流速の 推計值を得ることが求められる。地下水流れが速 い場合の熱応答試験では，有効熱伝導率よりも見 かけ上高い值，すなわち見かけ熱伝導率が得られ

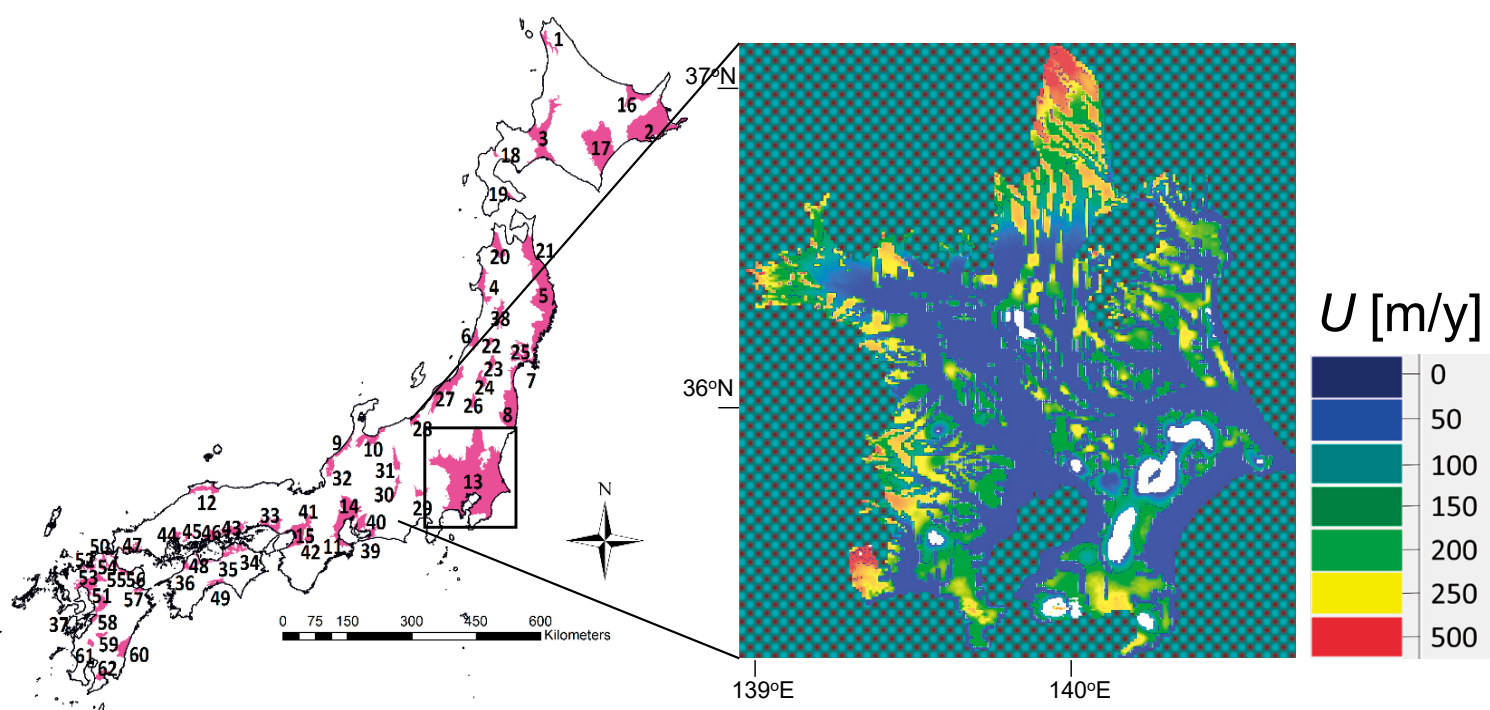

図 2 地下水流動シミュレーション対象 62 流域（a）と関東平野流域の計算ダルシー流速分布（b）

Fig. 262 water basins of Japan for groundwater flow simulation and one example results of simulated Darcy velocity in Kanto Basin. 
るが, その值は地下水流速だけでなく, 試験条 件（加熱量や加熱時間）や解析条件（熱媒体循環 温度の上昇勾配決定区間）にも依存する。このた め, 試験と条件が異なる実施設の地中熱交換器規 模の検討に見かけ熱伝導率をそのまま用いること はできず，有効熱伝導率とダルシー流速に分離す る必要がある。分離の方法には，これまでの逆解 析（Raymond et al., 2011など）に加え，より実用 的な方法として移動線熱源理論解に基づくフィッ ティング（Chae et al., 2020），加熱時の温度変化 勾配と地下水流速の関係を用いる手法（葛ほか, 2015）なども提案されている。また水平型地中熱 交換器を設置する浅層部の地下水流れに対して も, サーマルプローブを用いた試験法（葛ほか, 2006）やフーリエ数に対する無次元温度応答の関 係を用いる方法などが提案されている（Li et al., 2012)。

\section{3 オープンループシステム, 特に ATES の 導入可能性}

オープンループシステムは, 導入コストの低減 と安定した熱利用，なによりわが国の豊富な地下 水資源の有効利用の点から, 今後の導入が期待さ れる。特に季節間蓄熱が可能な ATES は近年, 実 証事業を通じ，その有効性が改めて報告されてお り（藤縄・冨樫，2012; 中曽ほか, 2013 ; 桂木ほ か, 2018a), 実施設への導入も進みつつある（若 林・坂部, 2016)。これまで地中熱利用の需要の ある都市部, 特に三大都市圈を含む臨海地域では 地下水の採取規制があり, ATES 導入の大きな制 約になってきた（桂木ほか, 2018b)。こうした 状況に対し, 大阪市等による実証事業を踏まえた
提言により採取規制地域でも国家戦略特区として 地盤沈下を起こさない範囲での管理の下 ATES 導 入を可能とする「環境省関係国家戦略特別区域法 第二十六条に規定する政令等規制事業に係る省令 の特例に関する措置を定める命令の一部を改正す る命令」が2019年 8 月27日公布された（大阪市, 2019）。これにより，ATESを中心としたオープ ンループシステムが関西圈を皮切りに今後, 関東 や中部その他規制地域にも導入される可能性が高 まった意義は大きく，わが国における今後の地中 熱利用の転換点になることが期待される。

国際的にはATES は出力 $10^{2} \sim 10^{3} \mathrm{~kW}$ 以上 の中〜大規模システムとして導入されており (Xu et al., 2013 ; Gehlin and Andersson, 2019), 高 効率運転によるライフサイクルコストの削減, ペイバックタイムの短縮効果が報告されてい る (Vanhoudt et al., 2011など )。IEA DHC/CHP （2018）によれば, 大規模（出力1 MW 以上） ATES システム導入の帯水層条件を表 1 のように まとめている。また世界の ATES 適正マップがデ ンマーク IF Technology 社によって公開されてい る(図 3)。図 3 によれば, 日本はATES の適正 が低位（low）から中位（Medium）で，特に関 東・大阪・北陸地方は高位 (High) とされてい る。ただし，わが国の場合，より小規模 $\left(10^{1} \sim\right.$ $10^{2} \mathrm{~kW}$ オーダー）のシステムを想定するのが現 実的であるため, 表 1 の条件に必ずしも当ては まらない。例えば，北海道北広島市における14 年間に渡るATESのモニタリング事例では，実 質的な透水層厚 $4 \mathrm{~m}$ でも平均約 $30 \mathrm{kWh}$, 回収率 約70\%で安定して稼㗢できた実績がある（中村 ほか, 2000)。図 3 のポテンシャルマップは解像

表 1

大規模（1 MW 以上）ATES における帯水層条件（IEA DTS/CTS, 2018）

Table 1 Criteria of unconsolidated aquifers for large-scale ATES systems.

\begin{tabular}{|c|c|c|}
\hline & $\begin{array}{ll}\text { 下 } & \text { 限 } \\
\end{array}$ & 上 限 \\
\hline 井戸深度 (m) & (注入必要圧から) & $\begin{array}{r}300 \\
(\text { 経済性から) }\end{array}$ \\
\hline 帯水層厚 (m) & 20 & 無し \\
\hline 透水係数 $(\mathrm{m} / \mathrm{s})$ & $\begin{array}{ll}1 \times 10^{-4} & \text { (層厚大) } \\
5 \times 10^{-4} & \text { (層厚小) }\end{array}$ & $1 \times 10^{-3} *$ \\
\hline 地下水流速 $(\mathrm{m} / \mathrm{d})$ & 0 & $0.3 *$ \\
\hline 静水位（地表からの深度, m) & 50 & -5 \\
\hline
\end{tabular}


度の点で実用的ではなく, 今後, 各地域におい てATES を含むオープンループシステムのポテン シャルマップの整備を進める必要がある。わが国 の ATES のポテンシャルマップの先駆けは札幌周 辺を対象とした濱田ほか (2004）があり，また大 阪での実証事業を踏まえ, 藤原ほか（2019）や大 阪府（2019）がポテンシャルマップを作成してい る。著者らはクローズドループシステムに対し全 国を統合的に評価する手法を提案したが（阪田ほ か, 2019), オープンループシステムにおいても 同様に全国共通で適用可能な評価手法の確立が必 要と考える。例えば先の IEA DHC/CHP は表 1 に加え, 層序, 粒径分布, 固結度, 地中温度, 地 下水流向, 地質構造 (亀裂分布), 帯水層構造, 熱貯留性と上下加圧層への熱漏洩なども導入指標 に挙げている。こうした導入指標を各地域の帯水 層毎に整理し，設備設計者が閲覧可能なデータ ベースに整備することが今後必要となろう。導入 指標として特に評価の課題となるのが, 採熱後の 復水（還元）に対する目詰まりリスクである。ス クリーン及び井戸周辺の地層の目詰まりは, 揚水 井より還元井の方が生じやすく, 細粒分の蓄積, 気泡発生, 溶出成分の形態変化・析出, 更に水質 変化に微生物活動に起因したバイオフィルム発生 といった, 物理的・化学的・生物学的に様々な要
因で発生する。先行する多くの導入事例のある欧 米でも，未だ目詰まり要因とメカニズムの解明は 定性的な範囲に留まるようである（Hähnlein et al., 2013; Jeong et al., 2018)。目詰まりリスクは設 計時のメンテナンスの不確実要因となっており, その予測評価は今後, オープンループシステムの 普及に向けて地下水学に課せられた解決すべき課 題と言える。また大規模施設になるほど採熱の繰 り返しにより，長期的な地下の熱污染とそれに起 因する環境変化が懸念される。こうした熱污染に よる実質的な環境影響についても未だ不明な点が 多く（斎藤・小松，2014）, その評価手法の確立 についても地下水学に課された課題と言える。

\section{4. 地中熱利用の国際的流れ}

地中熱の国際的な流れを紹介することで，わが 国の地中熱利用の次の展開や課題も見えてくる。 わが国に比べ地中熱利用が進む欧米, 中国では システムの大深度化・大規模化, 高密度化, 高 信頼化，ネットワーク化が進んでいる。大深度 化の例として，スウェーデンでは地中熱交換器 の長さが1980年には平均 $100 \mathrm{~m}$ 以下であったが, 掘削機の大型化により 2018 年には平均 $190 \mathrm{~m}$, 最 大深度 $500 \mathrm{~m}$, 家庭用でも平均 $176 \mathrm{~m}$ に達してい

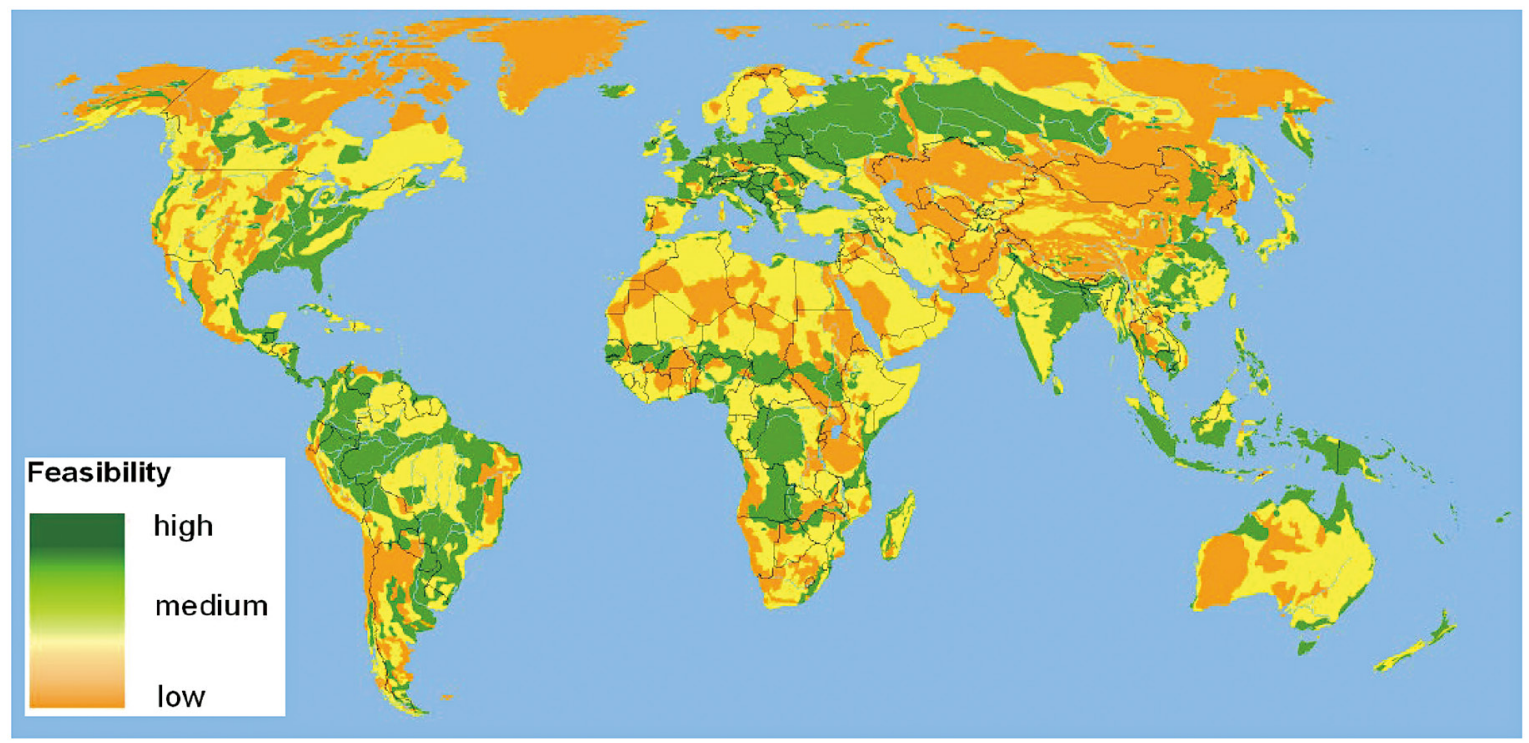

図 3 ATES 導入可能性マップ (IF Technology ホームページ, https://www.iftechnology.com/より)

Fig. 3 ATES feasibility map over the world. 
る（Gehlin and Anderson, 2019）。また大規模化 として, 出力 $10^{1} \mathrm{MW}$ オーダー, 地中熱交換器本 数が $10^{3}$ オーダーのシステムが次々導入されてい る。中国では, 北京国際会議場において冷房出 力 $17 \mathrm{MW}$, 暖房出力7.4 MW, $123 \mathrm{~m}$ の $\mathrm{BHE}$ が 1060本というシステムが導入されている（Zhang and $\mathrm{Wu}, 2014) 。 ま た 2019$ 年 9 月開港の北京大興 国際空港では257万 $\mathrm{m}^{2}$ の事務エリアに世界最大, 1 万本の地中熱交換器が設置された（北京市, 2018)。高密度化としては, スイスでは地中熱利 用システムの導入数は2013年時点でトータル約 84 千台（日本の約240倍, 国土面積は約 9 分の 1 ) に達している。これは $12 \mathrm{~kW}$ 標準システムに換 算して $1 \mathrm{~km}^{2}$ 当たり平均 3 台に相当する（Link et al., 2015)。こうした高密度化は，特に 5 千本の 地中熱交換器が埋設されるチューリッヒ市にお いて互いの熱干渉が問題視されている（Wieland, 2017)。高信頼化として, 前述の IEA DHP/CHP （2018）に加え, IEA ECES ANNEX21（2017）に おいて熱応答試験の規格化が行われたほか, IEA ECES ANNEX27（2019）ではボアホール型蓄 熱システムの規格化が進められている。ネット ワーク化としては, ドイッでは10年以上に渡って GSHP システムのデータ集中管理が既に行われて いる（Miara et al., 2017）ほか, 地域熱供給シス テムでは，より低温の地中熱をヒートポンプ技術 と組み合わせて熱源とする第 5 世代開発が進みつ つある（Buffa et al., 2019）。

これら地中熱利用先進国における先端的な技術 や知見に学ぶところは大きい。わが国において も，こうした先端施設と同等あるいはそれ以上の 地中熱利用システム, 特に, わが国に豊富に賦存 する地下水資源の有効利用として移流効果や蓄熱 効果を最大限活かす独自の地中熱利用システムの 導入を実現させることが社会全体へのインパクト となり，地中熱利用の普及に繋がると考える。

\section{5. まとめ}

東日本大震災以降のわが国のエネルギー需給環 境の変化を受け, 地中熱利用, 特に高効率設備と しての GSHP システムの導入拡大による民生部 門における省エネ貢献が期待される一方, 現状,
その導入数は伸び悩みを見せている。自治体に対 するアンケート調査を踏まえると, 普及の課題は 依然コスト削減にある。コスト削減のアプローチ として, クローズドループシステムに対しては, 移流効果を考慮する地中熱設計性能予測ツールの 活用と, その計算条件となる地下水流速のデー夕 ベースや現位置試験法を紹介した。またオープン ループシステムがコスト削減とともに，わが国の 地下水資源の有効利用の点からも導入が期待され る。特にATESは地下水採取規制緩和の新たな 枠組みの中, 今後の導入加速が期待されるが, そ の導入を促すには各地域に扔ける導入ポテンシャ ルの評価や設計実務者が閲覧可能な帯水層データ ベースの構築が求められる。特に評価指標の内, 還元井の目詰まりは現状, 発生要因やメカニズム の理解が定性的に留まっており, その予測法の確 立が今後の研究課題になる。併せて, 地中熱利用 システムの国際的な流れを紹介した。地中熱利用 先進国における知見や技術を学びつつ, わが国に おいても地下水資源を活かした先駆的システムの 開発が今後, 期待される。なお誌面の都合で割愛 したが，気候変動がもたらす地中熱利用への影 響も近年の研究トピックであり（Kharseh et al., 2015など), 別の機会に改めて紹介したい。本稿 が, 今後の地中熱利用の更なる発展に向けた本誌 読者の調査, 研究開発の一助となれば幸いであ る。

\section{参考文献}

井岡聖一郎・冨樫 聡・土原健雄 (2018)：特集「地 下水と地熱・地中熱エネルギーの利用」地下水と地 熱・地中熱エネルギーの利用. 地下水学会誌, 60 (4), 461-462.

内田洋平·與田佑季·藤井光·宮本重信·吉岡真弓 (2010) : 地中熱利用適地の選定方法その 1 地下水流動 - 熱輸 送解析と GIS を用いた地中熱利用適地マップの作 成. 日本地熱学会誌, 32 (4)，229-239.

大阪市 (2019): 帯水層蓄熱利用に向けた取り 組み, https://www.city.osaka.lg.jp/kankyo/ page/0000476996.html. (2019.10.25閲覧)

大阪府（2019）：地中熱ポテンシャルマップ.http://

www.pref.osaka.lg.jp/eneseisaku/sec/chichunetsu_ 
map.html. (2019.10.25閲覧)

落藤 澄 $(2002)$ : 地中熱利用と地下蓄熱の現状と課題.

日本地熱学会誌, 24, 315-327.

葛 隆生, 長野克則, 武田清香, 中村 靖 (2006)： サーマルプローブ法による地下水流速と温度応答の 関係に関する考察. 空気調和・衛生工学会論文集, 31 (112), 51-59.

葛 隆生・長野克則・中村 靖 (2015)：複層地盤を 考慮した地中熱交換器のシミュレーションツールの 開発とその応用. 日本冷凍空調学会論文集, 32 (3), 335-344.

桂木聖彦 - 藤井 光 - 井上 純 - 山谷 睦 - 黒沼 覚 (2018a) : 数值シミュレーションによる带水層蓄熱冷 暖房システムに扮ける効率的な帯水層への蓄熱方法 の検討. 日本地熱学会誌, 40 (2), 97-108.

桂木聖彦·藤井 光 - 黑沼 覚 - 井上 純 - 山谷 睦 沼澤喜一 (2018b)：日本国内に抢ける帯水層蓄熱 普及に向けた社会システム調査. 日本地熱学会誌,

40 (3)， 193-206.

環境省 (2018): 平成30 年度地中熱利用状況調查の集

計結果. https://www.env.go.jp/press/files/jp/111221. pdf. (2019.10.20閲覧)

経済産業省（2017）：平成28年度エネルギーに関 する年次報告（エネルギー白書2017） HTML 版. https://www.enecho.meti.go.jp/about/ whitepaper/2017html/2-1-1.html.（2019.10.22閲覧） 建築研究所 (2017)：平成28年省エネルギー基準に準

拠したエネルギー消費性能の評価に関する技術情報 (非住宅建築物), 地中熱ヒートポンプの評価方法 (夕 イプの判別方法). https://www.kenken.go.jp/becc/ building.html. (2019.10.10閲覧)

国土交通省（2019）：建築物省エネ法の改正について.

https://www.meti.go.jp/shingikai/enecho/shoene_ shinene/sho_energy/pdf/028_03_00.pdf. (2019.10.10 閲覧)

斎藤健志・小松登志子 (2014)：地中熱ヒートポンプが 地下環境に与える影響. 地下水学会誌, 56 (1), 1525.

阪田義隆・葛 隆生・長野克則 (2018a) : ライフサイ クルコストに基づく地中熱交換器規模の算定と地下 水流れがもたらす削減効果の分析. 地下水学会誌, 60 (4), 483-494.

阪田義隆 ·葛 隆生 - 長野克則 · 丸井敦尚（2018b）：
井戸データベースを用いた地盤情報推定システムの 開発その 2 : 確率加重平均による平均透水係数推定 法の評価. 地下水学会誌, 60 (3), 273-287.

阪田義隆・葛 隆生・長野克則（2019）：クローズド型 地中熱ヒートポンプシステムの地中熱交換器規模決 定に関する研究：個別シミュレーション決定法とそ の全国適用例. 日本地熱学会誌, 41 (3), 75-90.

阪田義隆 - 葛 隆生 - 長野克則 (2020) 地方自治体 ンケート調査による公共施設への地中熱ヒートポン プシステム導入実態分析. 土木学会論文集 $\mathrm{G}$ (環境), 76(5), I_197-I_204.

産業技術総合研究所 (2008)：平成20年度地下水賦 存量調查報告書, http://dl.ndl.go.jp/info：ndljp/ pid/11220696.（2019.10.30閲覧）

シェレスタガウラブ・内田洋平 ·吉岡真弓 · 藤井 光 . 井岡聖一郎 (2015)：地中熱ヒートポンプシステムに おけるポテンシャルマップの高度化. 日本地熱学会 誌, 37 (4), 133-141.

新エネルギー・産業技術総合開発機構（2017）：再生 可能エネルギー熱利用技術開発の取り組み. 平成 29 年度 NEDO 新エネルギー成果報告会熱利用分野予稿 集, 103-117.

東京都 (2014) : 東京地中熱ポテンシャルマップ.

http://www3.kankyo.metro.tokyo.jp/. (2020.2.10閲 覧)

長野克則 (2007a) : 1 章地中熱利用について, 地中熱ヒー トポンプシステム（北海道大学地中熱利用システム 工学講座編).オーム社, 11-12.

長野克則 (2007b)：6 章地中熱ヒートポンプシステム の評価と将来展望, 地中熱ヒートポンプシステム (北 海道大学地中熱利用システム工学講座編). オーム 社, 110-116.

中村真人 · 長野克則 - 横山真太郎 - 小端武治 - 濱田靖弘 落藤 澄 (2000)：廃夕イヤ焼却による带水層蓄熱と 活性炭生成. 空気調和·衛生工学会論文集, $25(77)$, 21-30.

中曽康壽·伊藤貴之 ·佐々木健太 - 藤井良平 - 中尾正喜 西岡真稔・鍋島美奈子（2013）：閉鎖性帯水層の昼夜 間蓄熱利用：第 1 報 - 帯水層蓄熱モデルの実験検証. 空気調和・衛生工学会誌, 38 (190), 11-20.

濱田靖弘, 中村真人, 窪田英樹, 丸谷 薰, 淵上栄樹, 長野克則（2004）国土数值情報を用いた地下帯水層 蓄熱システムの導入可能性に関する研究. 太陽エネ 
ルギー, 30 (5), 57-63.

藤原照幸·春日井麻里·濱田晃之·伊藤浩子. 北田奈緒子.

三田村宗樹・和田祐宏（2019）：地下水流動検討のた めの地盤モデルの構築と帯水層蓄熱 (ATES) 利用 ポテンシャルマップの作成. 地下水地盤環境・防災 · 計測技術に関するシンポジウム論文, 13-18.

藤縄克之 (2011)：1。はじめに, 誌面講座地下熱利用 技術. 地下水学会誌, 53 (1), 81-82.

藤縄克之・冨樫 聡 (2012)：9. 地下熱利用のための 数值解析技術, 誌面講座地下熱利用技術. 地下水学会 誌, 54 (1), 39-52.

北京市（2018）：グリーンエネルギーを活用する 新空港の建設推進. http://www.beijing.gov.cn/ zfxxgk/110002/gzdt53/2018-12/13/content_05efb872 776341199771a94ec7d2ffcb.shtml.（2019.10.10閲覧） 若林尚之・坂部高士（2016）：酒田市庁舎に扔ける地中 熱ヒートポンプシステム及び帯水層蓄熱を組み込ん だ熱源システムの計画概要. 日本建築学会技術報告 集, 22 (51)，627-630.

Buffa, S., Cozzini, M., D’Antoni, M., Baratieri, M. and Fedrizzi, R. (2019): 5th generation district heating and cooling systems: A review of existing cases in Europe. Renewable and Sustainable Energy Reviews, 104, 504522.

Chae, H., Sakata, Y., Katsura, T., Nagano, K. and Kondo, T. (2020): Estimation of fast groundwater flow velocity from thermal response test results. Energy \& Buildings, 206, 1-10.

Ferguson, G. (2015): Screening for heat transport by groundwater in closed geothermal systems. Groundwater, 53(3), 503-506.

Fujii, H., Inatomi, T., Itoi, R. and Uchida, Y. (2007): Development of suitability maps for ground-coupled heat pump systems using groundwater and heat transport models. Geothermics, 36, 459-472.

Gehlin, S. and Andersson, O. (2019): Geothermal Energy Use, Country Update for Sweden. European Geothermal Congress 2019, Den Haag, the Netherlands, 2019.

Hähnlein, S., Bayer, P., Ferguson, G. and Blume, P. (2013): Sustainability and policy for the thermal use of shallow geothermal energy. Energy Policy, 59, 914-925.

IEA DHC/CHP (2018): Integrated Cost-effective Large- scale Thermal Energy Storage for Smart District Heating and Cooling Design Aspects for Large-Scale Aquifer and Pit Thermal Energy Storage for District Heating and Cooling, 31-32. https://www.iea-dhc.org/ index.php?id=528. (2019.10.27閲覧)

IEA ECES ANNEX21 (2017): Thermal Response Test for Underground Thermal Energy Storages. http:// thermalresponsetest.org/. (2019.10.27閲覧)

IEA ECES ANNEX27 (2019): Quality Management in Design, Construction and Operation of Borehole Thermal Energy Storage Systems. http://www.ecesboresysqm.org/. (2019.10.27閲覧)

Jeong, H.Y., Jun, S.-C., Cheon, J.-Y. and Park, M. (2018): A review on clogging mechanisms and managements in aquifer storage and recovery applications. Geosciences Journal, 22, 667-679.

Li, H., Nagano, K. and Lai, Y. (2012): Heat transfer of a horizontal spiral heat exchanger under groundwater advection. International Journal of Heat and Mass Transfer, 55, 6819-6831.

Link, K., Rybach, L., Imhasly, S. and Wyss, R. (2015): Geothermal enegry in Switzerland- country update. Proceedings World Geothermal Congress 2015, Melbourne, Austria.

Lund, J.W. and Boyd, T.L. (2016): Direct utilization of geothermal energy 2015 worldwide review. Geothermics, 60, 66-93.

Kharseh, M., Altorkmany, K., Al-Khawaja, M and Hassani, F. (2015): Analysis of the effect of global climate change on ground source heat pump systems in different climate categories. Renewable Energy, 78, 219-225.

Miara, M., Gunter, D., Langner, R., Helmling, S. and Wapler, J. (2017): 10 years of heat pumps monitoring in Germany. 12th IEA Heat Pump Conference, Rotterdam, the Netherland, 2017.

Nagano, K. (2015): The progress of GSHP in Japan. IEA Heat Pump Center Newsletter, 33, 21-25.

Raymond, J. Therrien, R., Gosselin, L. and Lefebvre, R. (2011): Numerical analysis of thermal response tests with a groundwater flow and heat transfer model. Renewable Energy, 36, 315-324.

Sakata, Y., Katsura T., and Nagano, K.(2019): Nation- 
scale evaluation of required borehole heat exchangers considering advection effects of groundwater flow in Japan. IAH Congress 2019, Malaga, Spain.

Sakata, Y., Katsura, T., Nagano, K. (2020) Estimation of ground thermal conductivity through indicator kriging: Nation-scale application and vertical profile analysis in Japan. Geothermics, 88, 101881.

Xu, J., Wang, RZ. and Li, Y. (2013): A review of available technologies for seasonal thermal energy storage. Solar Energy, 103, 613-638.

Vanhoudt, D., Desmedt, J., van Bael, J., Robeyn, N. and Hoes, H. (2011): An aquifer thermal storage system in a Belgian hospital: Long-term experimental evaluation of energy and cost savings. Energy \& Buildings, 43, 3657-65.
VDI(Verein. Deutscher lngenieure) (2001): Thermal use of the ground. Ground source heat pump systems. VDI Richtlinien 4640, Part 2, 15-19.

Wieland, U.(2017): Geothermal storage for our cities. https://map.ethz.ch/content/main/en/newsund-veranstaltungen/eth-news/news/2017/01/ erdwaermespeicher-fuer-unsere-staedte.html. (2019.10.20閲覧)

Zhang, S. and Xu. W. (2014): Research and development of large scale ground source heat pump system, Asian Heat Pump \& Thermal Storage Technologies Network News Letter, https://www.hptcj.or.jp/Portals/0/ ahpnw/Newsletter/\%E2\%97\%8E3rd\%20AHPNW\%20 newsletter\%2020140925.pdf. (2019.10.20閲覧)

(受付：2019年11月12日，受理：2020年 3 月31日） 